\title{
Analysis of the efficiency of the in-cylinder catalyst to reduce exhaust emissions during the cold start combustion engine
}

The article concerns the use of an in-cylinder catalyst that allows reducing the exhaust emissions during diesel engine operation. This is an additional method of exhaust emission reduction - however, the active component is placed inside the combustion chamber hence much closest to the combustion process. This allows reducing the emissions at the very source (catalyst applied on the glow plugs). Such solutions are necessary because the reduction of exhaust emissions from vehicles is a key aspect of reducing the negative impact of transport on the environment.

Key words: exhaust emission, in-cylinder catalyst, diesel engine

\section{Introduction}

Due to the way passenger cars are used, especially during urban driving, they are characterized by low mileage between individual starts, so they often experience ignition in a cold state and operate in underheated engine conditions [6]. According to Scandinavian research [8], in Sweden, 2.7 billion cold engine starts in Sweden are made in passenger cars, and in Finland - 2.6 billion. Cold engine-starts cause about $90 \%$ of the total hydrocarbon and carbon monoxide emissions and $50-70 \%$ of oxides emissions from passenger cars in the Nordic countries, thus they are a significant contributor of harmful substances emissions from automotive sources.

Because the amount of time the engine spends operating in cold conditions is significant, more and more attention is brought to the problems caused by cold engine operation. When operating at low loads and idling the engine thermal condition is unstable and the reactions occurring inside and outside the cylinder (in the exhaust system) are somewhat disturbed. Additionally, fuel combustion in these conditions is partial and incomplete. Due to how passenger cars are used, mainly for urban driving, there is little distance covered between individual starts (Fig. 1), so they are often started from the cold engine state and operate in unfavorable engine conditions.

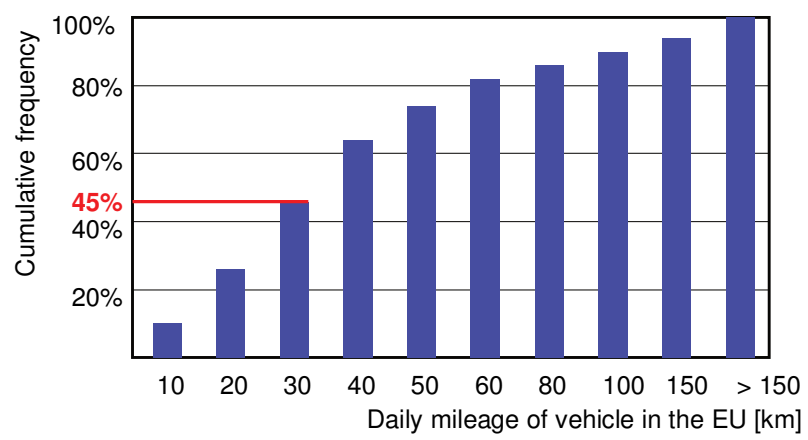

Fig. 1. Mileage of European passenger cars [14]

Figure 1 shows that $45 \%$ of routes travelled are shorter than $30 \mathrm{~km}$, so the engine is cold and the catalytic converter does not fully operate, especially when stationary - therefore it is possible to use various solutions to reduce this phenomenon [1]. In order to eliminate harmful exhaust emissions, it is pivotal to equip every vehicle with an exhaust aftertreatment system for flue gas whose composition, temperature and flow rates are constantly changed during operation. The catalytic reactors used in the automotive industry are expected to reduce harmful components of exhaust gases as well as to have high durability [10, 24]. A very important factor is controlling the parameters of exhaust gases, in particular their changes in the engine exhaust system $[11,23]$. The technology of exhaust aftertreatment systems is being continuously developed due to the ever lower emission limits. There are many solutions of exhaust aftertreatment systems, and their effectiveness often depends on the mutual relations and cooperation of individual system components (Fig. 2).
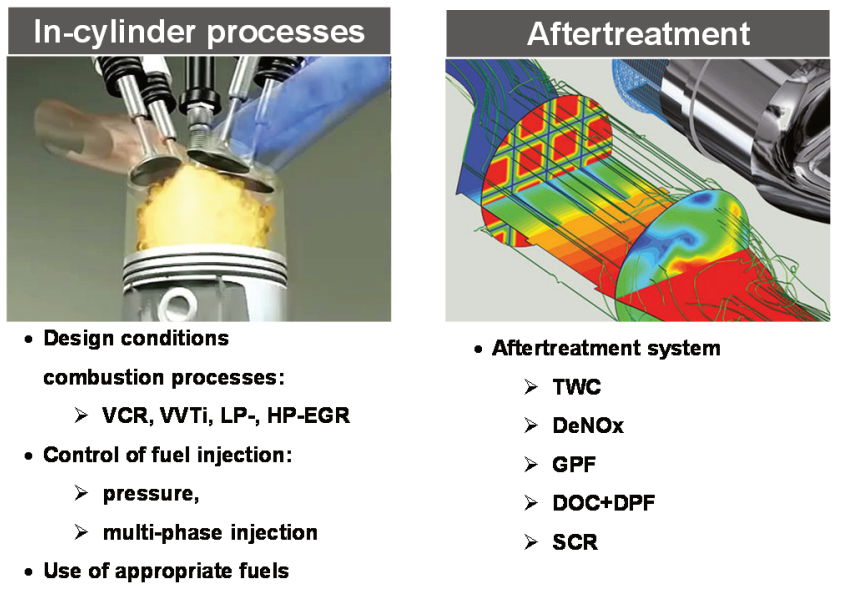

Fig. 2. Methods for reducing exhaust emissions; VCR (Variable Compression Ratio), VVTi (Variable Valve Timing with intelligence), ERG (Exhaust Gas Recirculation) of (LP - low pressure, HP - high pressure), TWC (Three Way Catalyst), Decrease $\mathrm{NO}_{\mathrm{x}}$ - systems for reducing the $\mathrm{NO}_{x}$ emissions, GPF (Gasoline Particle Filter), DOC (Diesel Oxidation Catalyst), SCR (Selective Catalytic Reduction)

Overall, toxicity is determined by local processes in the combustion chamber, which take place in dynamic conditions, occurring for a short duration (on the order of milli- 
seconds or shorter). Therefore, it is reasonable to introduce additional agents to improve the atomization, evaporation, diffusion of fuel vapors and their mixing with air, as well as for the oxidation of fuel, for example, the use of catalysts within the combustion chamber or immediately after the flue gas leave the chamber.

The use of a catalyst inside the combustion chamber can cause problems regarding the location, i.e. the choice of the surfaces and elements to be covered with catalytic materials. A separate problem arises as the issue of durability of the catalytic coatings used.

\section{Feasibility of in-cylinder catalysts use}

The need to reduce exhaust emissions from internal combustion engines has led to the introduction of multifunctional catalytic reactors used in both spark and compression ignition engines. However, there are problems associated with the use of catalytic converters, including the efficiency of carbon monoxide and hydrocarbons oxidation is only high when the engine is powered by a stoichiometric mixture, on top of that the reactor needs to reach its operating temperature (light-off). Obtaining the proper operating temperature of the catalytic converter is achieved primarily through its placement in the exhaust system. Thus, a concept was born to place the catalyst in the combustion chamber itself.

Research on ecological issues in internal combustion engines and the beneficial effects of internal catalyst, placed in the cylinder, on engine performance and exhaust emission were investigated as early as in the mid-twentieth century. The use of the catalytic coating in the cylinder were mainly aimed at reducing the smoke opacity in Diesel engines by reducing the ignition delay $[7,16,21,26]$. Other advantages were the subject of research in which the internal catalyst (covering the outlet valve with platinum) resulted in the reduction of carbon monoxide and hydrocarbon emissions in the Diesel engine powered by methanol [15] and diesel fuel [27, 28]. The issue of nitrogen oxides reduction using an in-cylinder catalyst is based on using a platinum catalyst [22], but due to the high costs of such a solution, it was postulated that it could be replaced with molybdenum compounds [25].

The results of research on in-cylinder catalysts were also published in articles [5, 9, 12, 13, 17, 18, 20], which have shown a positive effect that a catalytic layer on some elements of the combustion chamber has on reducing the concentration of carbon monoxide and hydrocarbons, which unfortunately depends on the properties of the catalyst used and the operating conditions of the internal combustion engine. Such tests were carried out only in stable conditions of engine operation, whereas in this article an attempt was made to determine the ecological benefits of using an incylinder catalyst mainly in the dynamic operating conditions of the compression ignition internal combustion engine as well as in real operation.

\section{Aim and scope of research}

Increasingly more emphasis is placed on reducing the negative environmental impact of combustion engine vehicles, both from the legal institutions of individual countries as well as international organizations and associations. This drives the search for ever more advanced technical solutions for the internal combustion engine that will limit this negative impact and meet the current exhaust emission limits [2-4, 19]. Among these activities, the most important ones are those that have a direct impact on the improvement of combustion and the reduction of the toxic exhaust components formation while still in the engine's combustion chamber. The distinguishing feature of this article is that it focuses mostly on conducting tests in the operating conditions corresponding to the engine cold start.

The formulation of the research aim lead to the following assumptions as part of the scope of research:

- the catalyst is applied on an easily replaceable element glow plug (test object),

- the material of the catalyst is platinum - it reduces the concentration of carbon monoxide and hydrocarbons and to a small extent allows for a reduction of solid particles in the Diesel engine,

- internal catalyst - platinum works mainly during startup and heating of the engine, that is why the tests will be carried out before the catalytic reactor (DOC),

- tests were performed comparatively: glow plug without a catalyst cover and covered with a catalyst (modified),

- additionally an analysis of the glow plug heating time and its influence on the exhaust emission was carried out,

- a Diesel engine with the Euro 4 emission category, the most frequently occurring in the European Union (1.3 JTD, MultiJet), was selected for the tests.

\section{Research methodology}

\subsection{Prototype components}

The subject of research and analysis were glow plugs with the following parameters (Fig. 3):

- catalog number: 0250203002,

- trade abbreviation (HKB): GLP016,

- material number (KSN), marketing number: 16,

- connection type: PIN,

- mounting depth: $28 \mathrm{~mm}$,

- threaded fitting 1: M8 $\times 1.0$,

- length: $120 \mathrm{~mm}$,

- control voltage: $11 \mathrm{~V}$,

- tilting angle forming the cone: $93^{\circ}$.

A new solution used in this research was the implementation of prototype glow plugs, with a $34 \mathrm{~mm}$ long heating section (4 mm longer compared to previous solutions - Fig. 4).

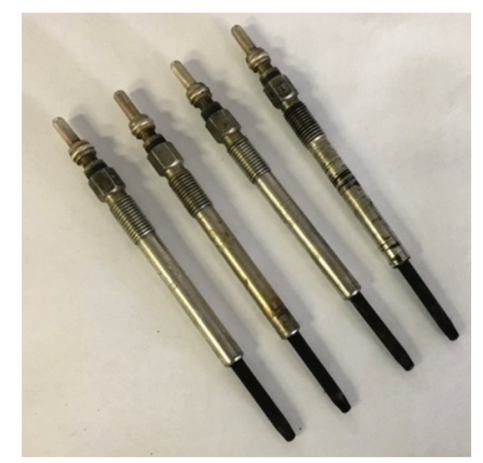

Fig. 3. Standard glow plugs (heating section length $-30 \mathrm{~mm}$ ) 


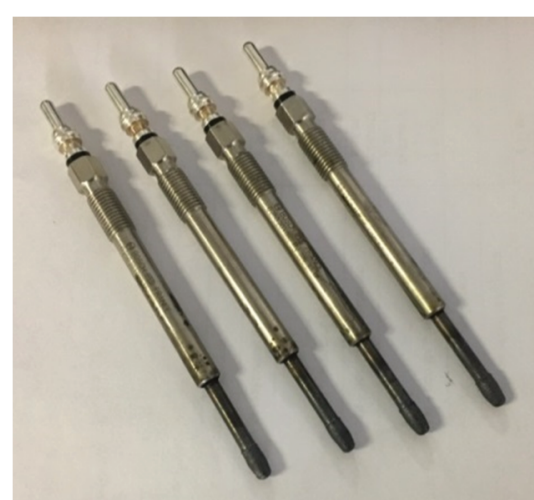

Fig. 4. Prototype glow plugs with an extended heating section length $(34 \mathrm{~mm})$

The new prototype glow plugs were longer by $4 \mathrm{~mm}$, which resulted in a $50 \%$ increased active surface area of the internal catalyst. The heating section was made of stainless steel (sheet) type INOX (18Cr9Ni), with a thickness of 0.05 $\mathrm{mm}$. Such a metal sheet is used for making catalytic reactors with a metal carrier. This made it possible to eliminate the ceramic layer that was applied to a standard plug with a catalytic coating having a heating section length of 30 $\mathrm{mm}$. The lack of a ceramic layer made it possible to reduce the thermal insulation, and as a result the heating of the glow plugs was faster leading to a higher catalytic layer operating temperature.

\subsection{Test object}

A compression ignition combustion engine was used for the research (as well as equipped in the passenger car used for the tests, with a mileage of $92,000 \mathrm{~km}$, where the engine met the Euro 4 emission standard). The test object was a supercharged engine with a $1.3 \mathrm{dm}^{3}$ displacement, with the designation 1.3 JTD (MultiJet) and Euro 4 emission class - the test stand is shown in Fig. 5.

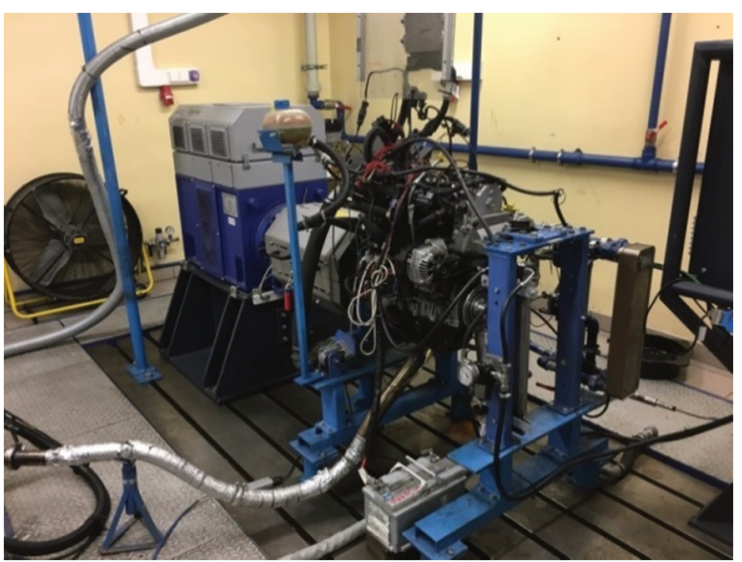

Fig. 5. The test engine mounted on the dynamometer along with the engine control unit

The exhaust aftertreatment system is typical for Diesel direct injection engines, i.e. a two-way catalytic converter (a particulate filter was not required in vehicles of this emission category). The choice of such a research object was dictated by the fact that more than $50 \%$ of cars in the European Union are equipped with such engines. At the same time, the Euro 4 emission standard was in force from January 1, 2006 to 2010, and the average age of cars im- ported to Poland is 11.5 years (of which $42 \%$ are with diesel engines). Therefore, the Diesel engine is the most representative engine in Europe and for Poland. Another reason is that it is an engine where the emission of carbon monoxide and hydrocarbons can be reduced easily - by simply replacing the glow plug.

\subsection{Measuring equipment}

The Semtech DS analyzer manufactured by Sensors was used to measure the concentration of harmful compounds in the exhaust gas. It allowed measurement of harmful compounds concentration including - carbon monoxide, hydrocarbons, nitrogen oxides and carbon dioxide. The analyzer processing unit received data directly from the engine diagnostic system. The analyzer consists of the measurement modules:

- FID (Flame Ionization Detector) used to determine the total hydrocarbon concentration in exhaust gases,

- NDUV (Non-Dispersive Ultraviolet), designed to measure the concentration of nitrogen oxide and nitrogen dioxide,

- NIDR (Non-Dispersive Infrared) infrared radiation, designed to measure the concentration of carbon monoxide and carbon dioxide,

- electrochemical for determining the oxygen content in the exhaust gas.

The TSI 3090 EPSS $^{\text {тм }}$ analyzer (Engine Exhaust Particle Sizer $^{\mathrm{TM}}$ Spectrometer) was used to study the particle size distribution of particulate matter. It enabled the measurement of a discrete range of particle diameters (in the range from $5.6 \mathrm{~nm}$ to $560 \mathrm{~nm}$ ) emitted in the exhaust gases based on their different velocity. Due to the device's data acquisition frequency of up to $10 \mathrm{~Hz}$, the analyzer can be used for the study of particulate emissions in transient engine states. The diagram of the setup of presented devices is shown in Fig. 6.

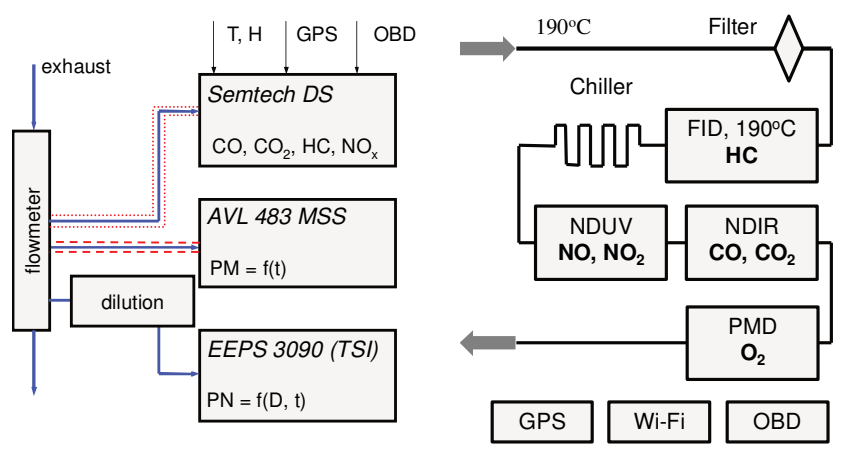

Fig. 6. Setup diagram of the measurement system used for testing the exhaust emission of gaseous and particulate compounds; $\mathrm{T}$ - ambient temperature, $\mathrm{H}$ - air humidity

\section{Measurement results}

Considering the ecological benefits of the research capabilities specified in the articles [2], another modification of catalytic-coated glow plugs was proposed. The proposal concerned the elongation of glow plugs, in such a way that the heating section coated with the catalyst protrudes as much as possible into the combustion chamber, and at the same time to maximally increase the area of its active reaction surface with combustion gases. Therefore, a longer 
glow plug (by about $4 \mathrm{~mm}$, the total length of the prototype plug was $34 \mathrm{~mm}$ long) was compared with a standard plug (with a heating section length of $30 \mathrm{~mm}$ ) and a catalyticcoated plug (with the heating section length of also $30 \mathrm{~mm}$ ). The tests were carried out in cold engine start conditions, and the measurement of exhaust emissions was performed upwind from the catalytic converter.

The tests were performed for the same exhaust components as for the previous research points. In the case of carbon monoxide concentration, in the whole measurement duration of $1200 \mathrm{~s}$, the smallest value was observed for the prototype glow plugs; just after engine start-up the concentration was $4000 \mathrm{ppm}$ and it was $20 \%$ lower than in the case of the shorter catalyst coated plug. Similar results were observed for the carbon monoxide emission intensity (constant exhaust gas mass flow). It should be noted that after about $600 \mathrm{~s}$ no significant differences are observed in both concentration and intensity of carbon monoxide emissions, regardless of the type of glow plugs and the length of the heating section of the catalyst coated glow plugs. As a result, carbon monoxide emissions in the range of 8-10 g were obtained during this study (Fig. 7).
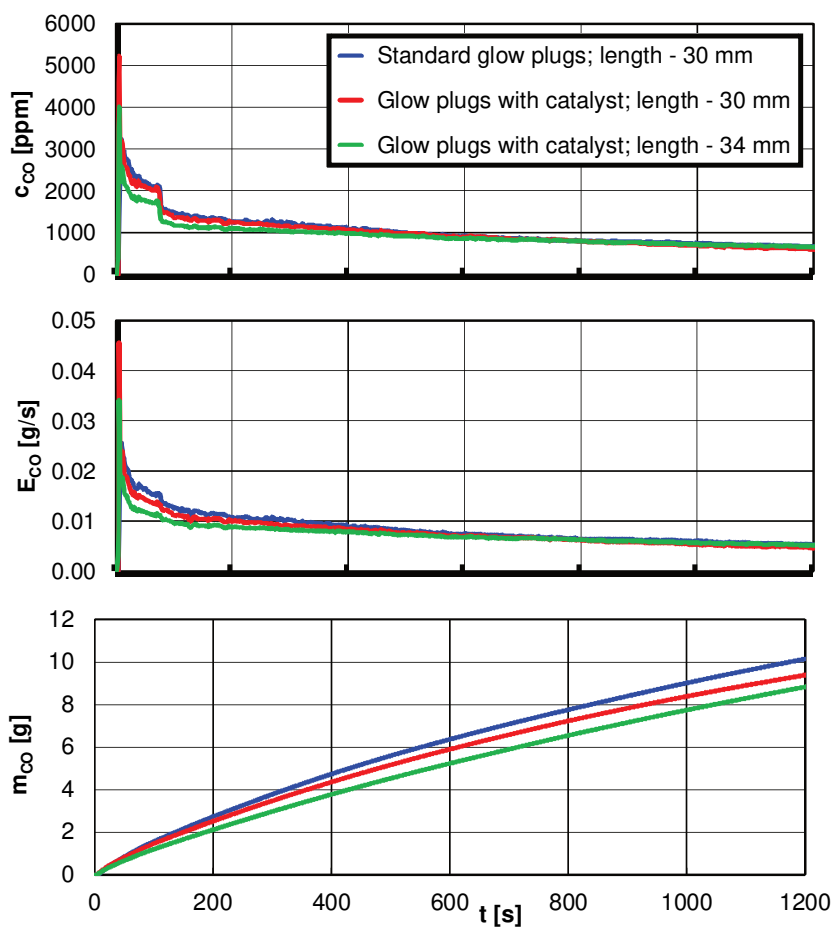

Fig. 7. Concentration, emission and emission intensity of carbon monoxide during tests of the Diesel engine depending on the type of glow plugs and the length of glow plugs coated with catalyst

A similar situation occurred in the case of hydrocarbon concentration analysis. The highest increase in concentration (over $600 \mathrm{ppm}$ ) was observed for the standard plugs, while similar values (around $600 \mathrm{ppm}$ ) were obtained during the study using catalyst coated plugs with a length of $30 \mathrm{~mm}$. For prototype plugs, this value was around 500 ppm. After a period of approximately $100 \mathrm{~s}$, the concentration was observed to stabilize at the level of 250-300 ppm along with a further slow reduction of concentration to the level of $150 \mathrm{ppm}$ at the end of the measurement test. The intensity of hydrocarbon emission had a very similar characteristic to the hydrocarbon concentration results, and the final value was similar for all cases and was about 0.0005 $\mathrm{g} / \mathrm{s}$. The hydrocarbon emission values, depending on the type of glow plugs and the length of the catalytic-coated glow plugs, ranged from 0.9-1.1 g (Fig. 8).
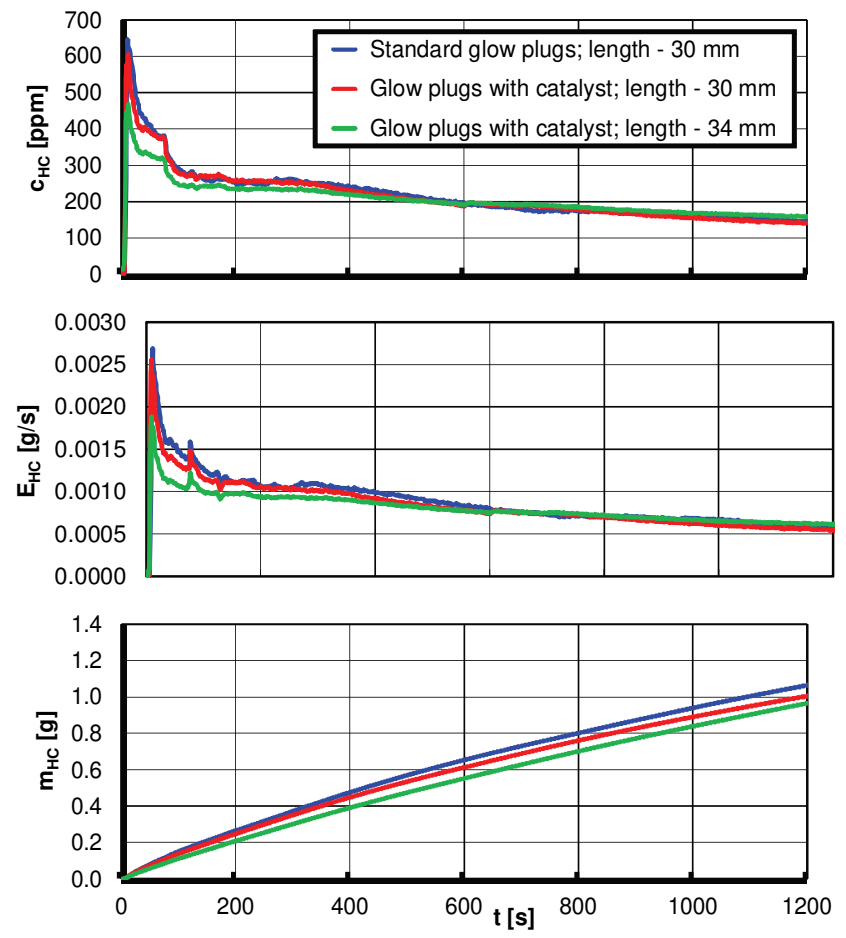

Fig. 8. Hydrocarbons emission, emission intensity, and concentration in Diesel engine tests depending on the type of glow plugs and the length of glow plugs section coated with the catalyst

A different character of the observed results was found in the case of nitrogen oxides concentration analysis. The smallest increase in concentration (about $120 \mathrm{ppm}$ ), but the largest eventual value, was observed in the case of the prototype glow plugs. The concentration of nitrogen oxides in the first period after the engine start was 50-70 ppm (lower values were observed for standard plugs). A similar situation was in the case of the nitrogen oxide emission intensity analysis - the largest values were typically observed for the prototype plugs. After a period of approximately $100 \mathrm{~s}$, a rapid increase in the emission intensity of nitrogen oxides to the value of about $0.0005-0.001 \mathrm{~g} / \mathrm{s}$ was observed, caused by the change of engine settings (consistent operation of the engine controller independent of the type of glow plugs used). Obtained nitrogen oxides emission values for the three considered cases of the glow plug types and length of the catalytic-coated section were in the range of 0.9-1.1 g (Fig. 9).

Particle number analysis does not provide easily differentiated test results. All concentration measurement results are very similar in character and values to each other. The final particle number values allow a proper assessment of the environmental benefits of the glow plugs used. The number of particles in the entire measurement test for different types of glow plugs ranged between $4-5.5 \cdot 10^{11}$ (Fig. 10). 

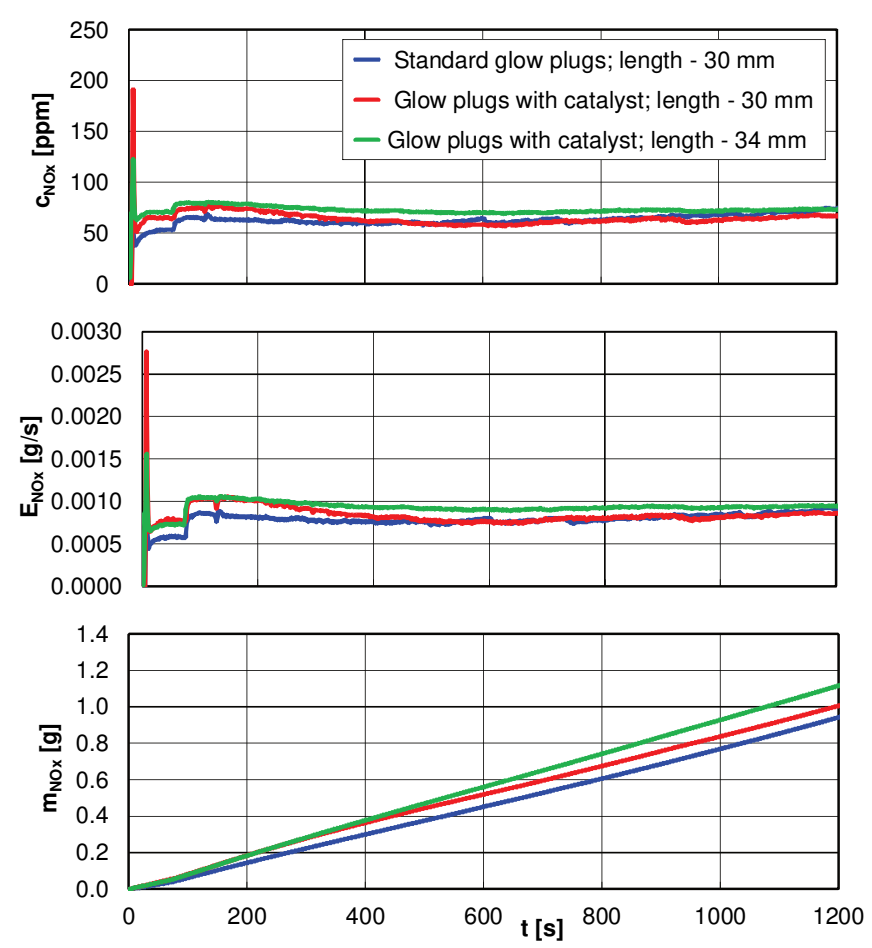

Fig. 9. Nitrogen oxides emission, emission intensity, and concentration in Diesel engine tests depending on the type of glow plugs and the length of glow plugs section coated with the catalyst
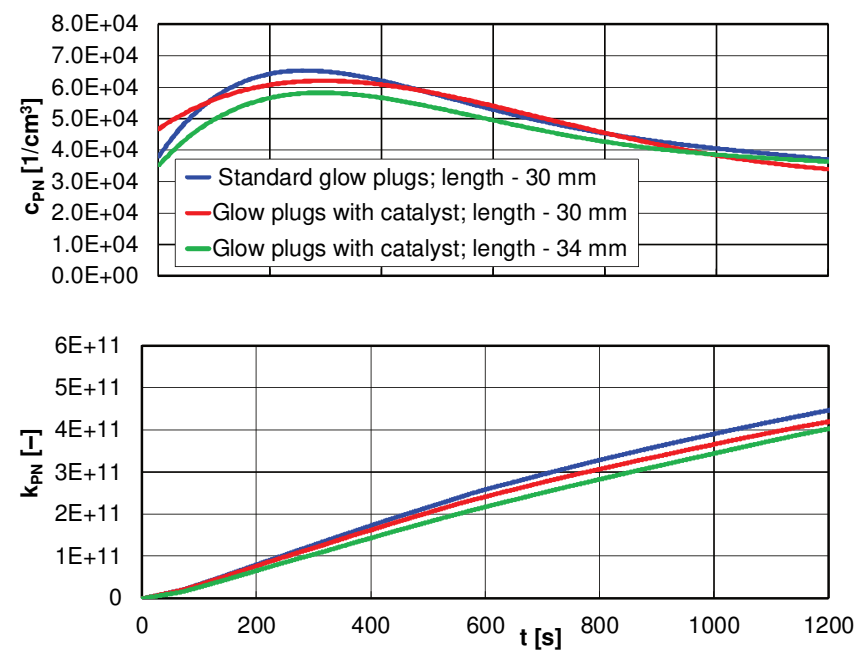

Fig. 10. The numerical concentration and the particle number in Diesel engine tests depending on the type of glow plugs and the length of glow plugs section coated with the catalyst

The smallest differences in the analyzed results were observed in carbon dioxide emission for different glow plugs with different catalyst coated section lengths. The lowest level of repeatability occurred only in the first $200 \mathrm{~s}$ after the engine start, while the later measurements of the concentration and emission intensity values were the same. Carbon dioxide emissions also changed only in the range of 270-300 g depending on the type of glow plugs and the catalyst coated section length (Fig. 11).

\section{Measurement uncertainty analysis}

Most of the discussion regarding the variability and inaccuracy of data when testing the concentration (or emission) of exhaust emissions from internal combustion en- gines concerns measurement uncertainty treated in a holistic way. The most important factors affecting the measurement uncertainty of exhaust emissions in these models were the uncertainties related to the vehicle engine and the ambient conditions. However, comparing the changes that have occurred in the regulations regarding the permitted limit values of individual exhaust components, it should be noted that the limits have been reduced several fold, which also resulted in a significant exhaust emissions concentration reduction and absolute results in grams per cycle (given cycle measurement). The exhaust gas analyzer is also of great importance when performing measurements within the test framework. Most importantly its measuring range, repeatability of measurements as well as the accuracy of measuring the concentration of individual compounds in the background (in the ambient air).
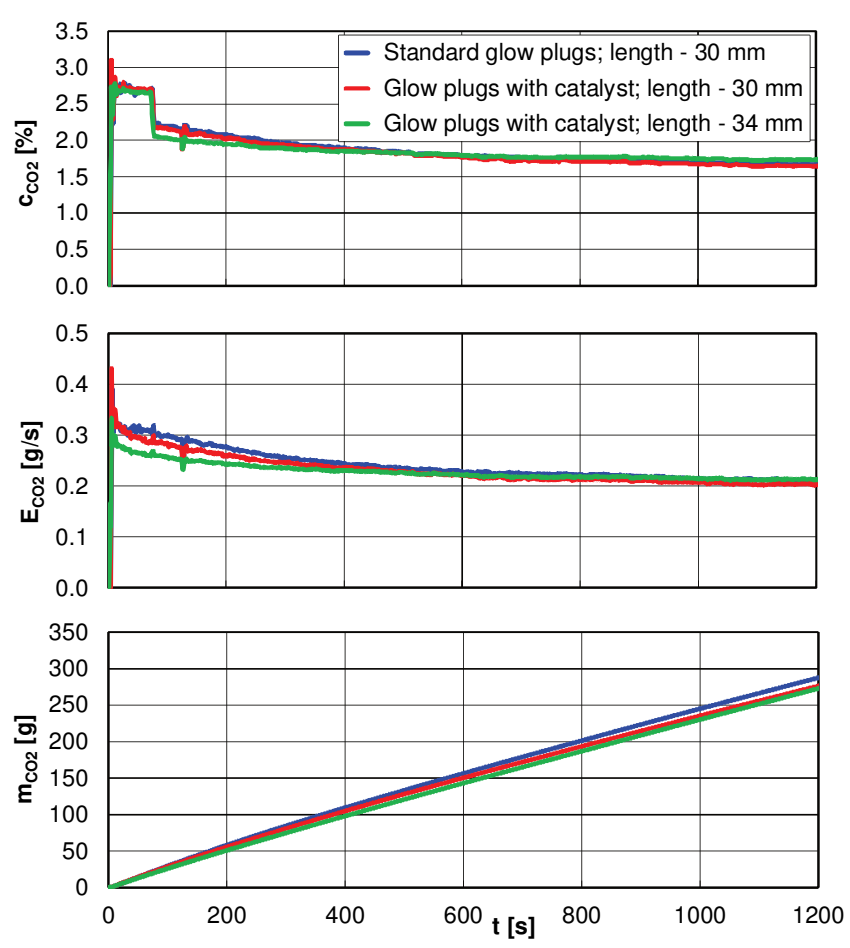

Fig. 11. Carbon dioxide emission, emission intensity, and concentration in Diesel engine tests depending on the type of glow plugs and the length of glow plugs section coated with the catalyst

The following analysis presents a method for determining the emission measurements separation between the standard and catalytic coated glow plugs. In other words, the analysis concerns a situation in which the obtained results can be treated as different, i.e. their average values at the appropriate level of significance are different. To prove this, 20 measurements of emissions of selected exhaust compounds were performed during cold engine start for standard and catalyst coated plugs (to make the article more concise, an example result of carbon monoxide emission was shown). The measurements were taken upwind from the catalytic converter to eliminate the additional effect of exhaust aftertreatment devices.

Considering the results of measurements of carbon monoxide emission (standard glow plugs), the variability range of this compound was $(9.8 \mathrm{~g}, 10.4 \mathrm{~g}$ ], and the highest 
frequency of results (6 measurements out of 20) was the range (10 g, $10.1 \mathrm{~g}$ ] (Fig. 12a). The approximation of the discrete probability density with normal distribution with expected value estimation and variance is shown in Fig. $12 \mathrm{~b}$. For the results of carbon monoxide emission tests (modified glow plugs), a similar characteristic of obtained results was found (Fig. 13a). The results variability range was from $9.1 \mathrm{~g}$ to $9.7 \mathrm{~g}$, and the most results (8 data points) were in the range $(9.4 \mathrm{~g}, 9.5 \mathrm{~g}]$. The probability density graph was similar to the graph from Fig. 12b, and was also consistent with the graph of the normal distribution (Fig. 13b).

In order to establish that the average values of carbon monoxide emissions for standard and catalyst coated plugs are different, the hypothesis that the expected values of the average results obtained are the same was verified (at the significance level of 0.05$)$. The hypotheses in the form $\mathrm{H}_{0}$ :

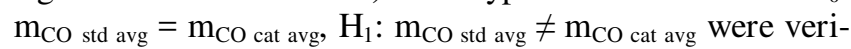
fied using the statistics:

$$
\mathrm{t}_{u}=\frac{\mathrm{m}_{\mathrm{CO} \text { std avg }}-\mathrm{m}_{\mathrm{CO} \text { cat avg }}}{\sqrt{\frac{\mathrm{n}_{\mathrm{std}} \mathrm{S}_{\mathrm{CO} \text { std }}^{2}+\mathrm{n}_{\text {cat }} \mathrm{S}_{\mathrm{CO} \text { cat }}^{2}}{\mathrm{n}_{\text {std }}+\mathrm{n}_{\text {cat }}-2}\left(\frac{1}{\mathrm{n}_{\text {std }}}+\frac{1}{\mathrm{n}_{\text {cat }}}\right)}}
$$

a)

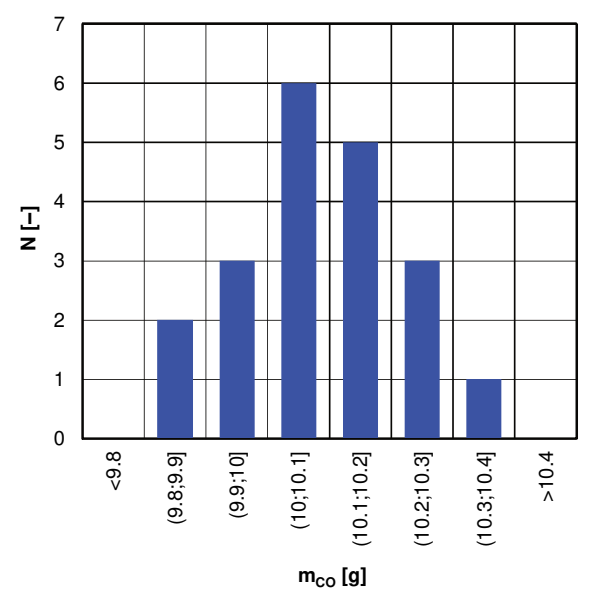

where: $\mathrm{m}_{\mathrm{CO} \text { std avg }}=10.08 \mathrm{~g}, \mathrm{~m}_{\mathrm{CO} \text { cat avg }}=9.41 \mathrm{~g}, \mathrm{n}_{\text {std }}=20$, $\mathrm{n}_{\text {cat }}=20, \mathrm{~S}_{\mathrm{CO} \text { std }}=0.1236 \mathrm{~g}, \mathrm{~S}_{\mathrm{CO} \text { cat }}=0.1221 \mathrm{~g}$.

Which results in:

$$
\mathrm{t}_{\mathrm{u}}=\frac{10.08-19.41}{\sqrt{\frac{20 \times 0.1236^{2}+20 \times 0.1221^{2}}{20+20-2}\left(\frac{1}{20}+\frac{1}{20}\right)}}=16.9
$$

From the t-Student's distribution tables for the significance level $\alpha=0.05$ and $n_{1}+n_{2}-2=38$ degrees of freedom, the critical value was $t_{u, c r i t}=2.024$. Because the test result value for average values of carbon monoxide emission is determined by the inequality $\left|t_{u}\right|=16.9>t_{u, c r i t}$, the hypothesis $\mathrm{H}_{0}$ should be rejected, so the average carbon monoxide emission values for measurements using standard and catalytic coated plugs are different. Figure 14 also shows that the intervals determined by average carbon monoxide emission values and two-fold standard deviation do not overlap. It is a confirmation that the obtained average values of carbon monoxide emissions using the standard and modified glow plugs are different (at the significance level of 0.05 ).

b)

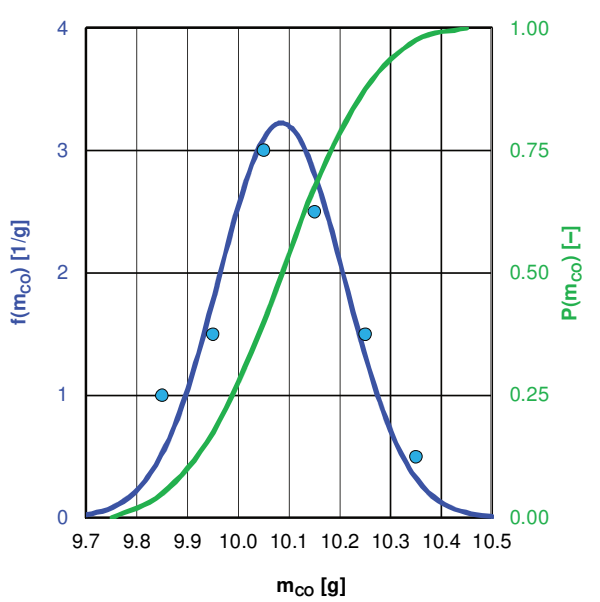

Fig. 12. Carbon monoxide emission histogram (standard plugs) in value ranges (a), approximated probability density and its cumulative distribution function (b)

a)

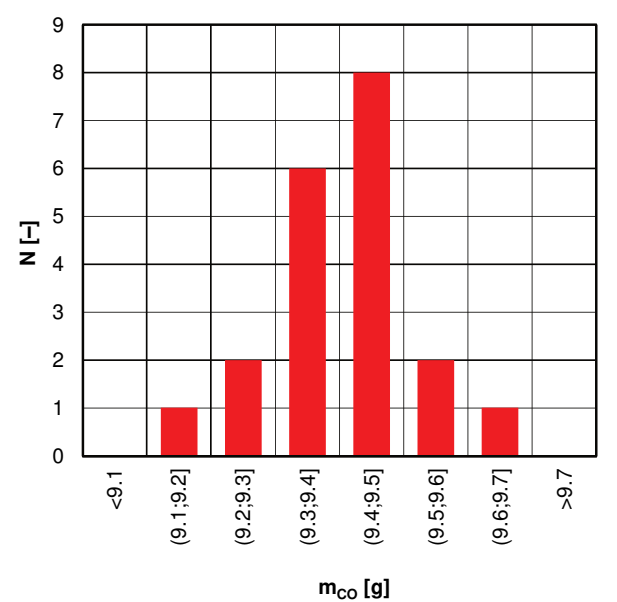

b)

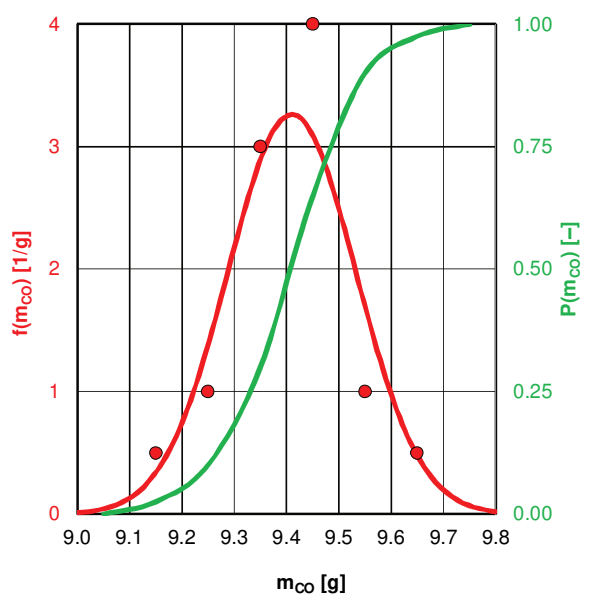

Fig. 13. Carbon monoxide emission histogram (catalyst-coated plugs) in the value ranges (a), approximated probability density and its cumulative distribution function (b) 


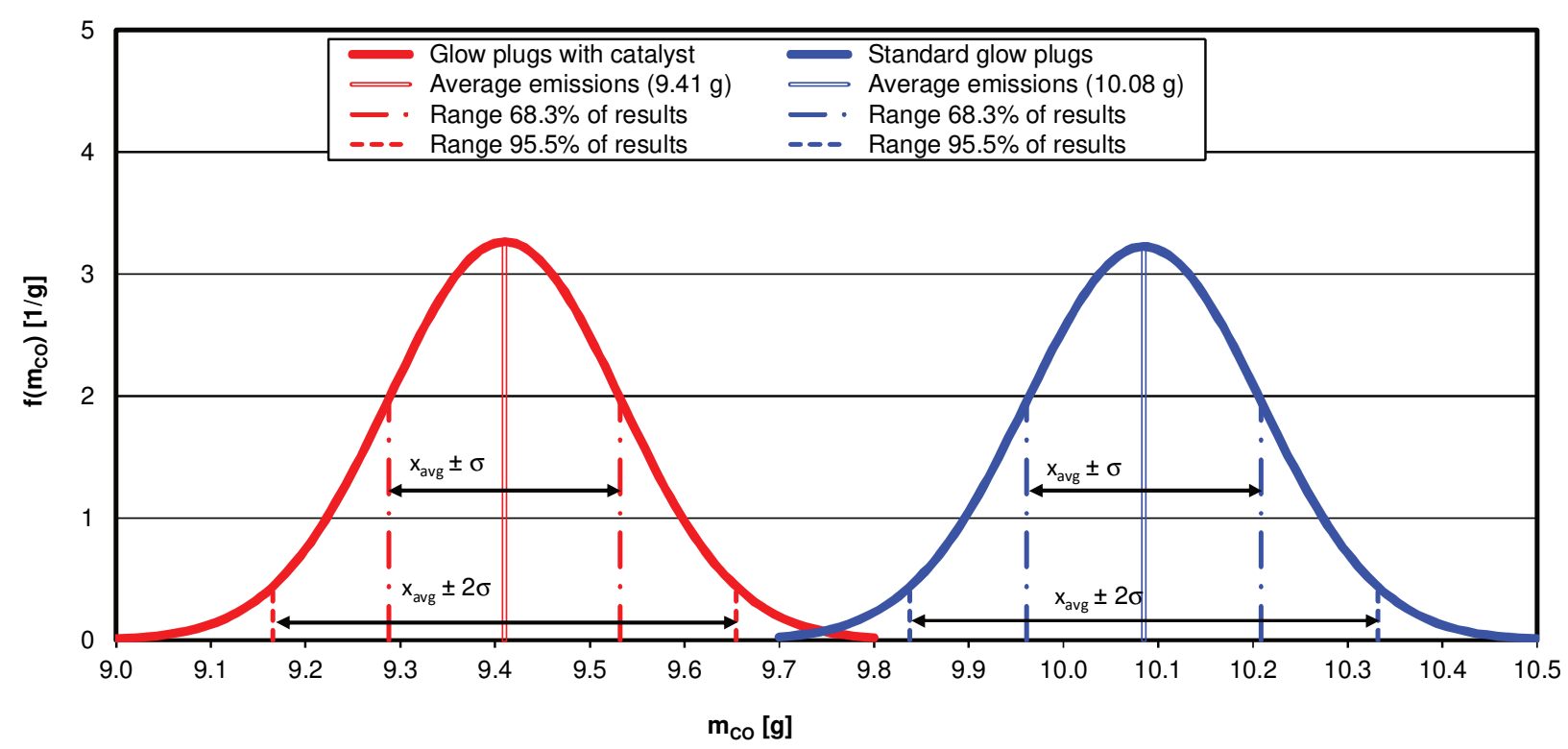

Fig. 14. Probability density for two values of expected carbon monoxide emissions for standard and catalyst coated glow plug tests

\section{Conclusions}

The following results are only comparative for plugs with a catalytic coating $30 \mathrm{~mm}$ long and $34 \mathrm{~mm}$ long (prototype). Studies on the influence of the length of catalyst coated glow plugs during cold engine start on the exhaust emission values, resulted in the following conclusions:

a) carbon monoxide emission (Fig. 15a):

- catalyst coated candles, heating section $30 \mathrm{~mm}: 9.4 \mathrm{~g}$,

- catalyst coated candles, heating section $34 \mathrm{~mm}: 8.8 \mathrm{~g}$,

b) hydrocarbons emission (Fig. 15b):

- catalyst coated candles, heating section $30 \mathrm{~mm}: 1.01 \mathrm{~g}$,

- catalyst coated candles, heating section $34 \mathrm{~mm}: 0.97 \mathrm{~g}$,

c) nitrogen oxides emission (Fig. 15c):

- catalyst coated candles, heating section $30 \mathrm{~mm}: 1.01 \mathrm{~g}$,

- catalyst coated candles, heating section $34 \mathrm{~mm}: 1.12 \mathrm{~g}$,

d) carbon dioxide emission (Fig. 15d):

- catalyst coated candles, heating section $30 \mathrm{~mm}: 277 \mathrm{~g}$,

- catalyst coated candles, heating section $34 \mathrm{~mm}: 273 \mathrm{~g}$,

e) particle number emission (Fig. 15e):

- catalyst coated candles, heating section $30 \mathrm{~mm}$ : $4.2 \cdot 10^{11}$,

- catalyst coated candles, heating section $34 \mathrm{~mm}$ : $4.0 \cdot 10^{11}$.

During comparative tests of engine exhaust emissions with catalyst coated glow plugs with various lengths of heating elements for the Diesel engine cold start, the following results were obtained (values given relative to the emission values for a catalyst coated glow plug with a heating element length of $30 \mathrm{~mm}$ ):

- a relative reduction in carbon monoxide emissions by $12.9 \%$,

- a relative reduction of hydrocarbon emissions by $9.3 \%$,

- a relative increase in emissions of nitrogen oxides by $14.3 \%$,

- a relative decrease in the particle number by $9.8 \%$,

- a relative reduction of carbon dioxide emissions by $5.1 \%$. a)

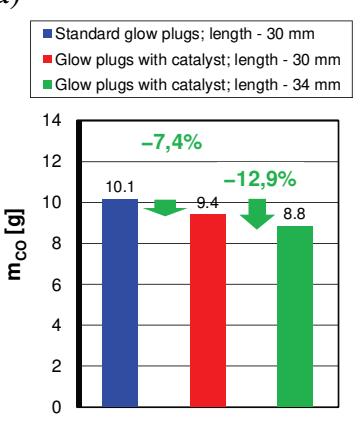

b)

- Standard glow plugs; length - $30 \mathrm{~mm}$
- Glow plugs with catalyst; length - $30 \mathrm{~mm}$ - Glow plugs with catalyst; length $-30 \mathrm{~mm}$
- Glow plugs with catalyst; length $-34 \mathrm{~mm}$

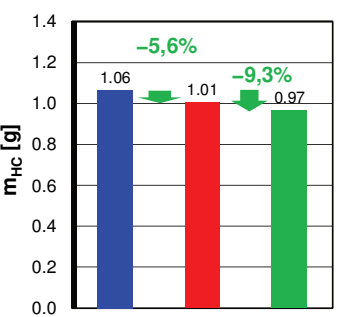

c)

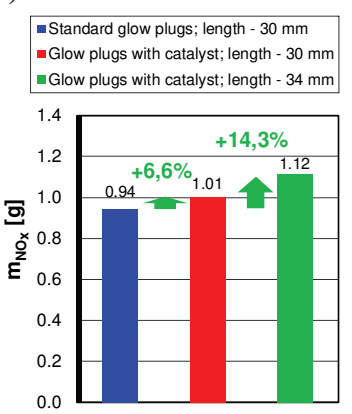

d)

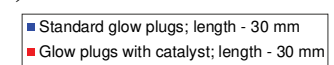

- Glow plugs with catalyst: length - $30 \mathrm{~mm}$

$\square$ Glow plugs with catalyst; length - $34 \mathrm{~mm}$

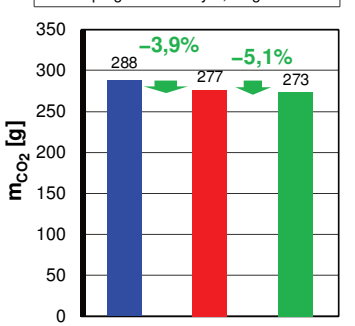

e)

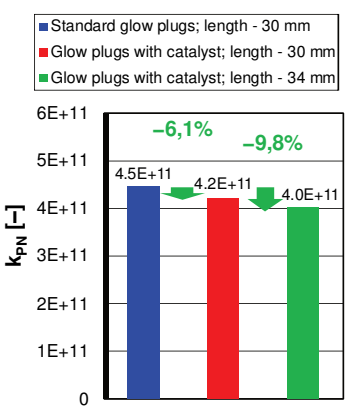

Fig. 15. Emissions comparison of carbon monoxide, hydrocarbons, nitrogen oxides, carbon dioxide and the particle number depending on the type and length of glow plugs 


\section{Bibliography}

[1] AHLERS, S., BRÜCK, R., CARTUS, T., STOCK, H. Procedure and design of exhaust systems to fulfill all emission limits during real driving conditions: In Use Conformity, 39th International Vienna Motor Symposium. Vienna 2018.

[2] ANDRYCH-ZALEWSKA, M. Improving the environmental performance of the internal combustion engine by the use of in-cylinder catalyst. Combustion Engines. 2017, 1.

[3] ANDRYCH-ZALEWSKA, M. The possibilities and development of in-cylinder catalytic coating. Journal of KONES. 2017, 3.

[4] ANDRYCH-ZALEWSKA, M. Wpływ katalizatora wewnętrznego na emisję spalin w stanach pracy silnika o zapłonie samoczynnym odpowiadających jego użytkowaniu trakcyjnemu, Rozprawa doktorska. Poznań 2018.

[5] ANDRYCH-ZALEWSKA, M., WALKOWIAK, W., KOLANEK, C. Heat release in spark ignition engine with internal catalyst. Journal of KONES. 2015, 4.

[6] BIELACZYC, P., MERKISZ, J., PIELECHA, J. Stan cieplny silnika spalinowego a emisja związków szkodliwych. Wyd. Politechniki Poznańskiej, Poznań 2001.

[7] BRADSTREET, S. Flame sprayed catalyst coatings. The Clay Products News and Ceramic Record. 1961, 24.

[8] BURK, P., HOCHMUTH, J., ANDERSON, D., et al. Cold start hydrocarbon emissions control. Automotive Engineering. 1995, 10.

[9] HU, Z., LADOMMATOS, N. Reduction of unburnt hydrocarbon emissions from spark ignition engines using incylinder catalysts. Journal of Automobile Engineering. 1996, 210.

[10] KENECHT, W. Diesel engine development in view of reduced emission standards, Energy, 2008, 33.

[11] KOZAK, M., MERKISZ, J., BIELACZYC, P. Wpływ właściwości paliwa na emisję szkodliwych składników spalin przez samochód osobowy napędzany silnikiem o zapłonie samoczynnym. Silniki spalinowe. 2005, 1.

[12] MELLO, J., BEZAIRE, D., SRIRAMULU, S., WEBER, R. Performance and economics of catalytic glow plugs and shields in direct injection natural gas engines for the next generation natural gas vehicle program. Final report. National Renewable Energy Laboratory, NREL/SR-540-34286, 2003.

[13] MERKISZ, J., PIELECHA, J. Możliwości obniżenia emisji cząstek stałych w silnikach ZS poprzez zastosowanie katalizatora. IV Sympozjum EKODIESEL'98. Warszawa 1998.

[14] MERKISZ, J., PIELECHA, J., RADZIMIRSKI, S. New trends in emission control in the European Union. Springer Tracts on Transportation and Traffic. 2014, 4.

[15] MITCHELL, W., LITZINGER, T., LEE, W. Effects of incylinder catalysts on combustion and emissions of a D.I.

Prof. Jerzy Merkisz, DSc., DEng. - Faculty of Transport Engineering, Poznan University of Technology.

e-mail: jerzy.merkisz@put.poznan.pl diesel engine fuelled on neat methanol. SAE Technical Paper 920688, 1992.

[16] NAVALIHINA, M., ROMANOVSKY, B., TOPCHIEVA, K. Investigation of acidic properties of zeolite by high temperature poisoning technique, Catalysis and Kinetic. 1971, 12.

[17] NEDUNCHEZCHIAN, N., DHANDAPANI, S. Effects of in-cylinder catalytic coating on the performance of a twostroke spark ignition engine. Indian Journal of Engineering \& Materials Sciences. 2001, 8.

[18] NORMAND, B., FERVEL, V., CODDET, C., NIKITINE, V. Tribological properties of plasma sprayed alumina-titania coatings: role and control of the microstructure. Surface and Coatings Technology. 2000, 123.

[19] PIELECHA, J. Identyfikacja parametrów cząstek stałych z silników spalinowych. Rozprawa habilitacyjna. Wyd. Politechniki Poznańskiej, Poznań 2012.

[20] REKSA, M., ANDRYCH-ZALEWSKA, M., MIHAYLOV, V. The impact analysis of hydroxide mixture addition on the combustion process in the diesel engine. MTM Machines, Technologies, Materials. 2014, 2.

[21] SAMAHOV, A., ZAIDMAN, M., CHIZHIK, M. Change of activity of catalysts during exploitation. Novosibirsk: Science, Siberia branch 1976.

[22] SAMSONOV, G. Catalytic properties of refractory compounds and principles of creation of refractory materials with preassigned properties. Principles of Choice of Catalysts for Heterogeneous. Catalysis. 1966, 11.

[23] SITNIK, L., ANDRYCH-ZALEWSKA, M. Statistics of indicated pressure in combustion engine. Scientific Conference on Automotive Vehicles and Combustion Engines, KONMOT 2016.

[24] SITNIK, L., ANDRYCH-ZALEWSKA, M., HALLER, P., WŁOSTOWSKI, R. Badania emisji gazowego silnika o zapłonie iskrowym $\mathrm{w}$ aspekcie parametrów sterowania. Raporty Wydziatu Mechanicznego Politechniki Wroctawskiej. 2015, 137.

[25] USOV, U., SKVORZOVA, E., KLUSHNIKOVA, G. Dehydrogenating methylhexane on chromia-alumina and molybdena-alumina catalysts. Neftekhimiya. 1963, 3.

[26] VASILEV, I., GAVRILINKO, P., ZVONOV, V. Method of definition of catalytic activity of combustion chamber surface of IC engine. USSR Author Certificate 1312206, 1987.

[27] WINKLER, M., PARKER, D. The role of diesel ceramic coatings in reducing automotive emissions and improving combustion efficiency. SAE Technical Paper 930158, 1993.

[28] WONG, V., BAUER, W., KAMO, R. et al. Assessment of thermal barrier coatings for IC engines. SAE Technical Paper 950980, 1995.

Monika Andrych-Zalewska, DEng. - Faculty of Mechanical Engineering, Wrocław University of Technology.

e-mail: monika.andrych@pwr.edu.pl

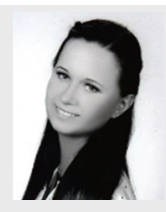

Prof. Jacek Pielecha, DSc., DEng. - Faculty of Transport Engineering, Poznan University of Technology.

e-mail: jacek.pielecha@put.poznan.pl 